\title{
Correction: miR-22 promotes stem cell traits via activating Wnt/ $\beta$-catenin signaling in cutaneous squamous cell carcinoma
}

Shukai Yuan, Peitao Zhang, Liqi Wen, Shikai Jia, Yufan Wu, Zhenlei Zhang, Lizhao Guan, Zhengquan Yu (D) and Li Zhao (D)

(c) The Author(s) 2022

Oncogene (2022) 41:1674-1676; https://doi.org/10.1038/s41388-022-02188-y

Correction to: Oncogene https://doi.org/10.1038/s41388-021-

01973-5, published online 3 August 2021

In this article two text marking errors on the Fig. $3 \mathrm{~F}$ and Supplementary Fig. $3 \mathrm{~A}$ in this paper. The "miR=22" should be corrected as "miR-22" on Fig. 3F. The "Inhibitor-miR-22" and "Inhibitor-NC" on Supplementary Fig. 3A Left (A431) were on the wrong sites and their positions should be reversed. 
The correct figures are given below.

A
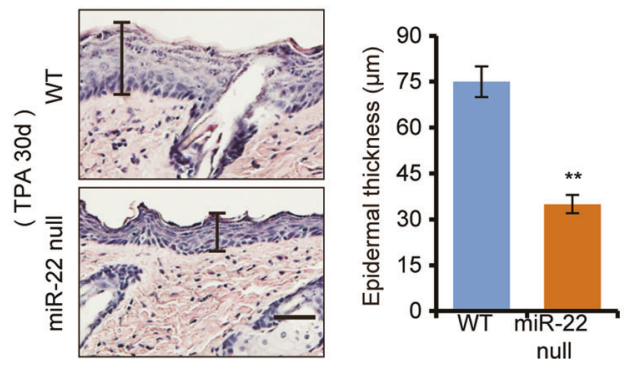

C

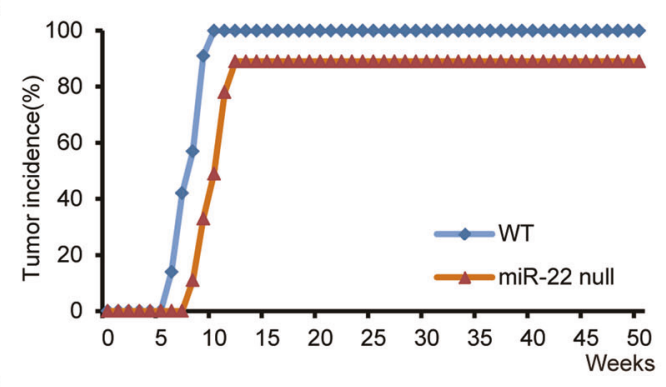

D

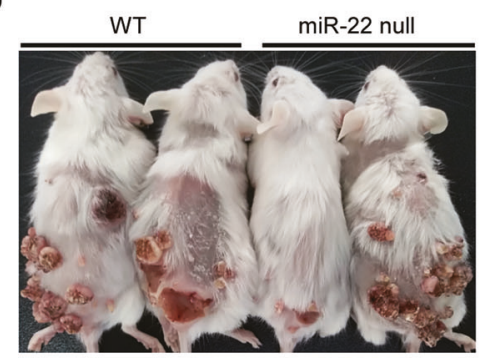

G
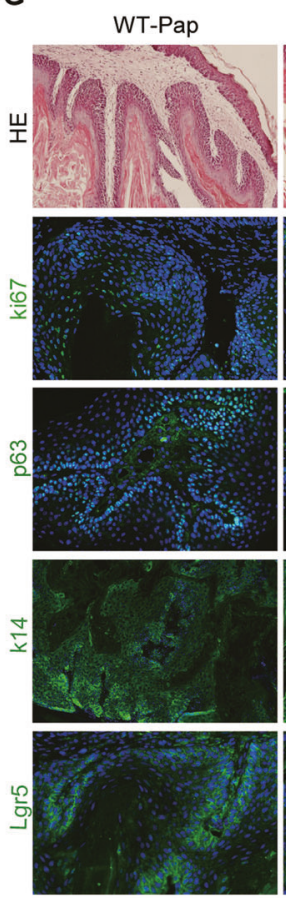

miR-22 null Pap

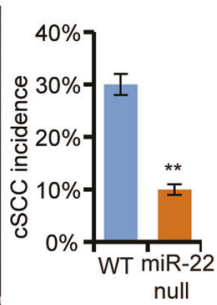

null

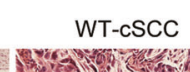

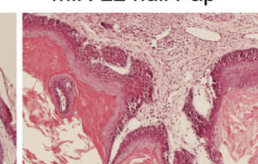
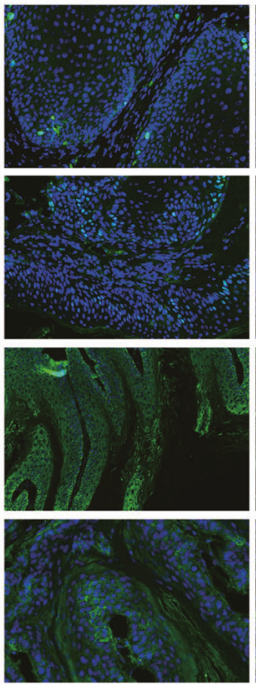

B
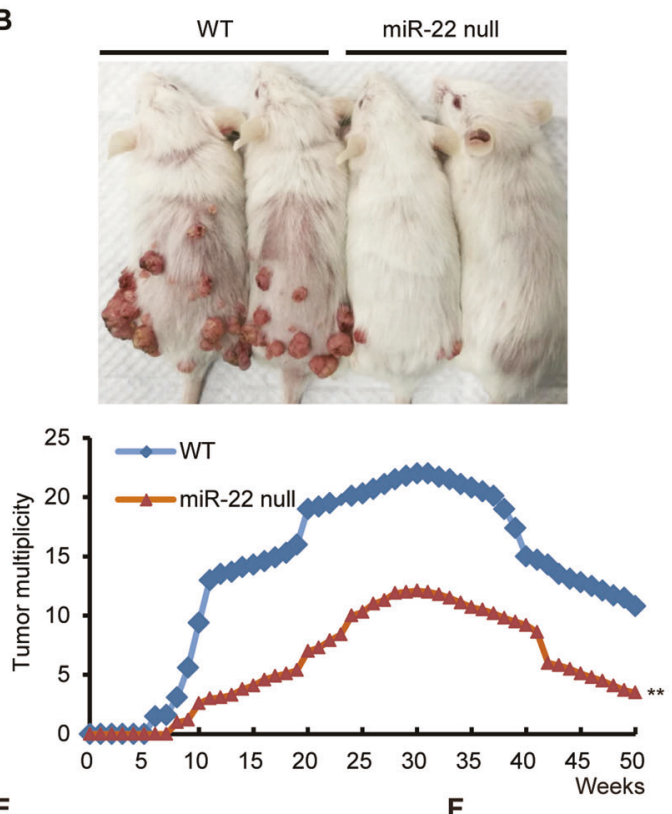

E

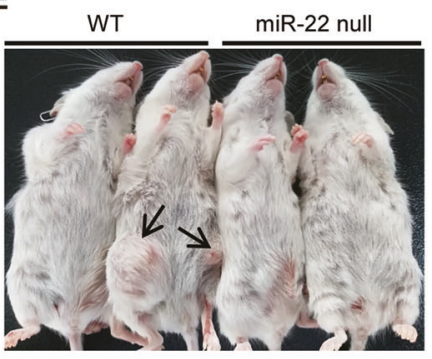

miR-22 null cSCC

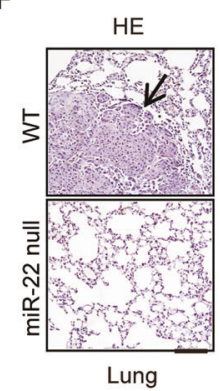

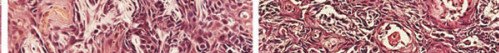

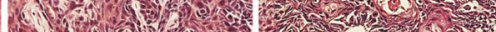

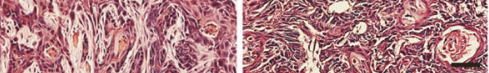
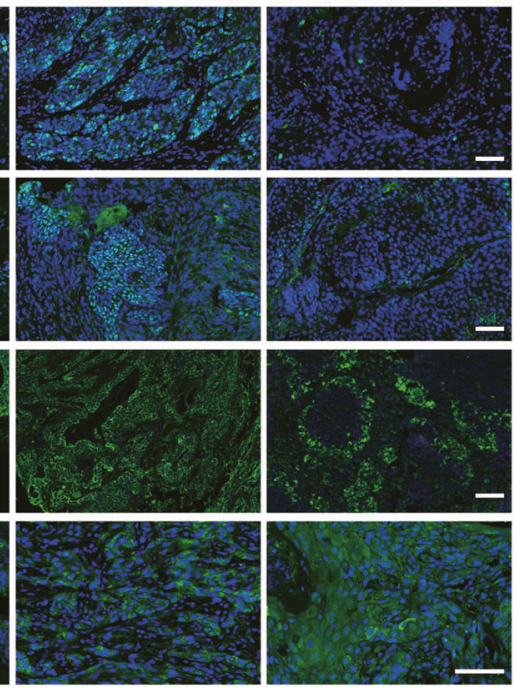

The original article has been corrected. 
(c) (1) Open Access This article is licensed under a Creative Commons Attribution 4.0 International License, which permits use, sharing, adaptation, distribution and reproduction in any medium or format, as long as you give appropriate credit to the original author(s) and the source, provide a link to the Creative Commons license, and indicate if changes were made. The images or other third party material in this article are included in the article's Creative Commons license, unless indicated otherwise in a credit line to the material. If material is not included in the article's Creative Commons license and your intended use is not permitted by statutory regulation or exceeds the permitted use, you will need to obtain permission directly from the copyright holder. To view a copy of this license, visit http://creativecommons. org/licenses/by/4.0/.

(c) The Author(s) 2022 